\title{
Response of neutral boundary layers to changes of roughness
}

\author{
Larsen, Søren Ejling; Mortensen, Niels Gylling; Sempreviva, Anna Maria; Troen, Ib
}

Published in:

Meteorology and Wind Energy Department. Annual Progress Report. 1 January - 31 December 1987

Publication date:

1988

Document Version

Publisher's PDF, also known as Version of record

Link back to DTU Orbit

Citation (APA):

Larsen, S. E., Mortensen, N. G., Sempreviva, A. M., \& Troen, I. (1988). Response of neutral boundary layers to changes of roughness. In Meteorology and Wind Energy Department. Annual Progress Report. 1 January - 31 December 1987 (pp. 15-43). Risø National Laboratory. Denmark. Forskningscenter Risoe. Risoe-R No. 560

\section{General rights}

Copyright and moral rights for the publications made accessible in the public portal are retained by the authors and/or other copyright owners and it is a condition of accessing publications that users recognise and abide by the legal requirements associated with these rights.

- Users may download and print one copy of any publication from the public portal for the purpose of private study or research.

- You may not further distribute the material or use it for any profit-making activity or commercial gain

- You may freely distribute the URL identifying the publication in the public portal 


\title{
2 Response of neutral boundary layers to changes of roughness
}

\author{
S.E. Larsen, N.G. Mortensen, Anna Maria Sempreviva \\ and I. Troen
}

\subsection{Introduction}

When air under neutral conditions flows from one surface to another with a different roughness, an internal boundary layer (IBL) grows downwind from the roughness change. This phenomenon has been quite extensively described in literature as regards short fetches (e.g. Bradley (1968), Panofsky (1973), Businger (1972), Peterson et al. (1979), Rao et al. (1974)).

For long fetches the IBL grows until it fills up the planetary boundary layer and a new equilibrium is established between geostrophic wind and surface stress in accordance with the geostrophic drag laws. This part of the IBL growth has not been as thoroughly described as the short-fetch situation. Discussions are presented in Taylor (1969), Jensen (1978), Hedegaard and Larsen (1982) and Larsen et al. (1982).

Here, we relate the problems of neutral flow response to changing roughness conditions to a data set obtained during the JYLEX experiment in which meteorological parameters were measured along four masts placed from the coastline to $30 \mathrm{~km}$ inland at the North Sea coast of Jutland in Denmark.

\subsection{The experimental set-up}

The JYLEX experiment (JYLland EXperiment) was established on the west coast of Jylland (the Danish name for Jutland) to study the change of surface layer characteristics as a function of the distance to the sea.

In the experiment meteorological variables were measured along four masts placed from the shore line and up to $30 \mathrm{~km}$ inland. The positions of the masts are shown in Fig. 1. The shore-line mast M1 was a $32-\mathrm{m}$ mast while the rest of the masts were $24 \mathrm{~m}$ high. Figure 2 illustrates the appearance of the shore-line mast and one of the inland masts. Table 1 summarizes the measurements conducted at each mast.

The experiment lasted from May 1982 until June 1984 yielding 25 months of data. The measurements were recorded every 10 minutes. Of the data 

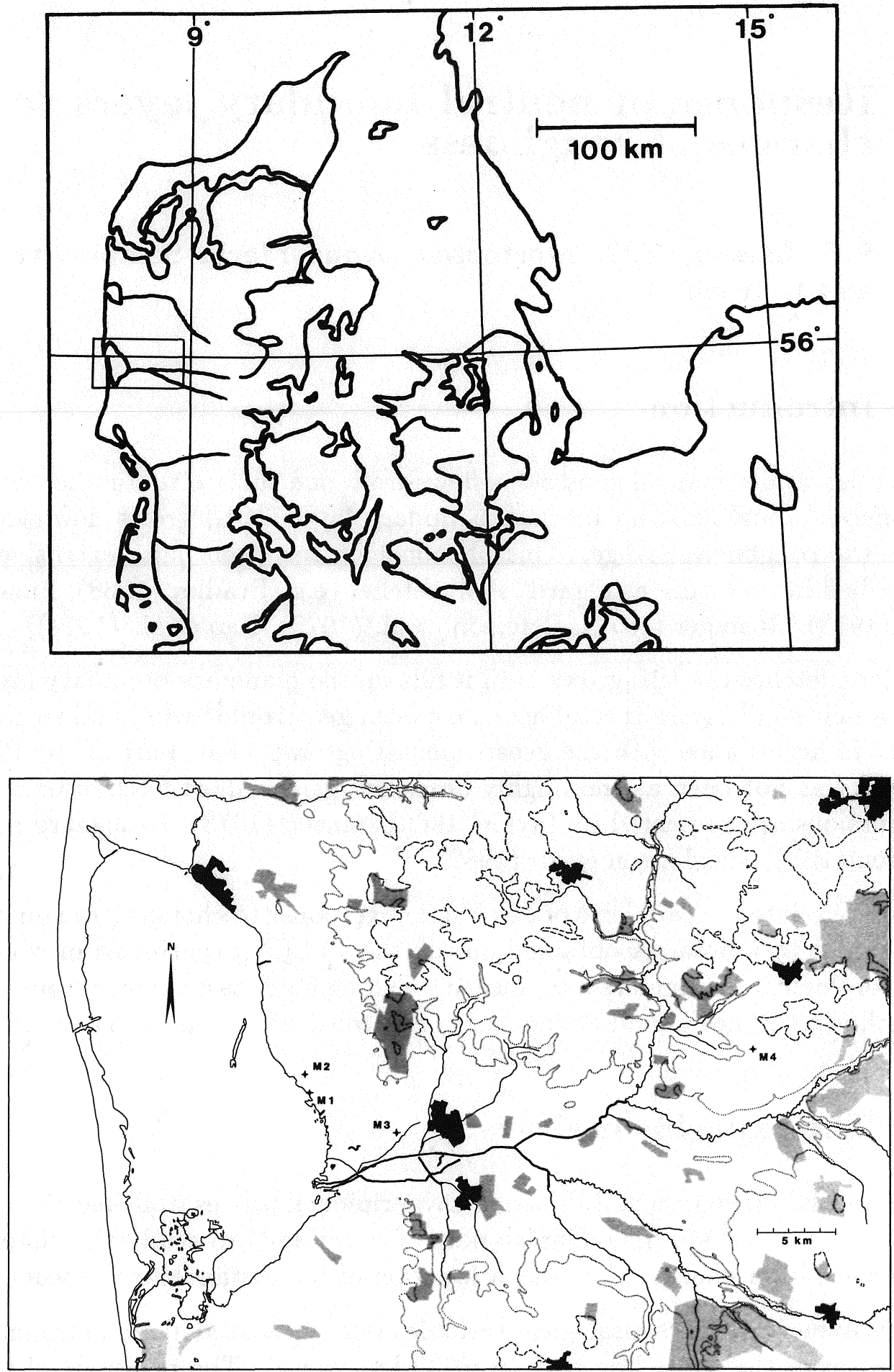

Figure 1: Maps of the experimental site. Figure 1a shows the overall area, while Fig. $1 \mathrm{~b}$ gives a more detailed map of the site, indicating positions of the masts. In Fig. 1b main terrain features are also indicated such as cities, forests, and heights of terrain. 

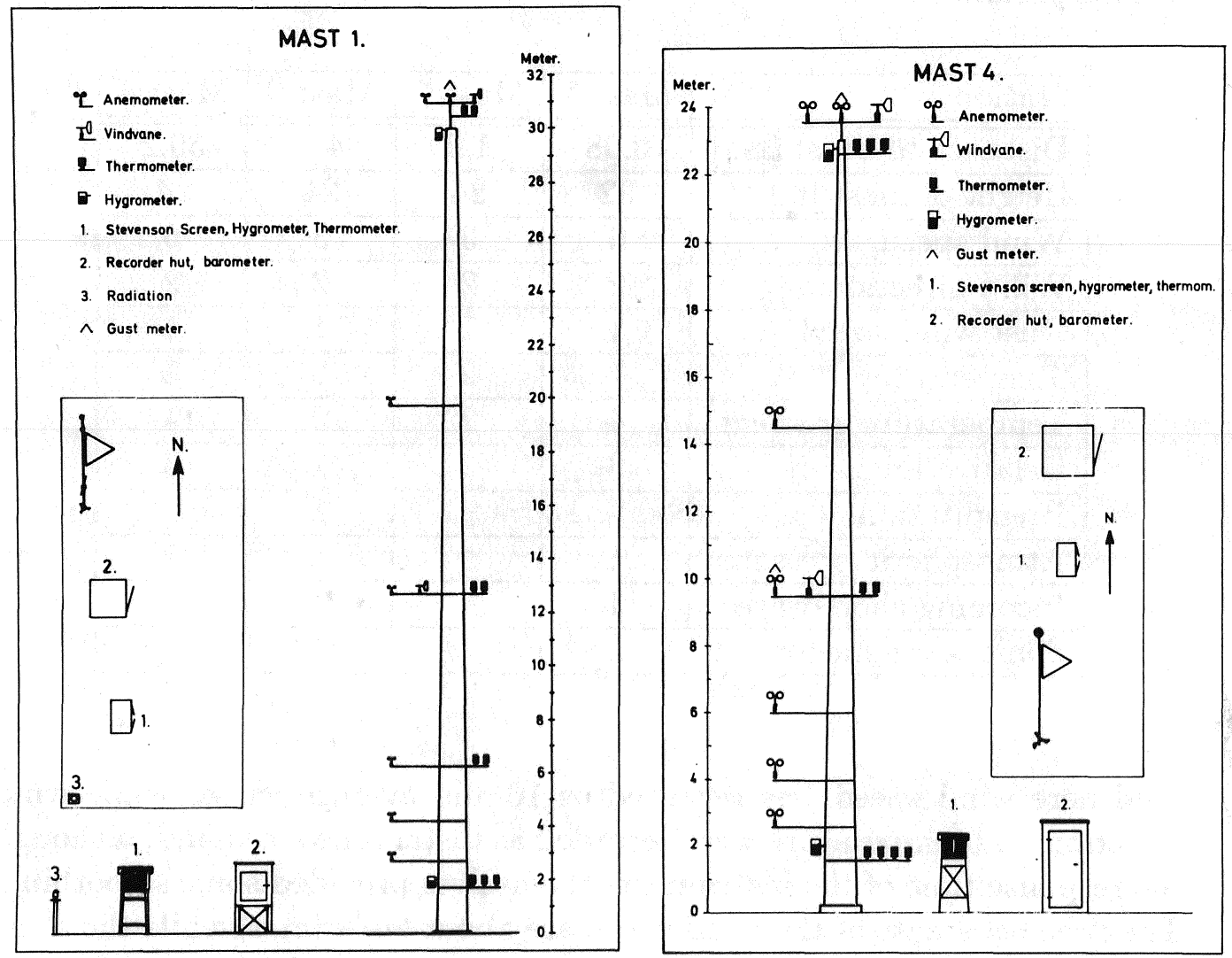

Figure 2: Appearance of the meteorological masts used during the experiment. Figure $2 \mathrm{a}$ shows the mast at the shore line, mast 1 , while Fig. $2 \mathrm{~b}$ shows one of the inland masts, mast 4. 
Table 1: The JYLEX experiment. For each of the four masts are shown distance to the coast, height, and number of measurement levels for the various parameters.

\begin{tabular}{|l|c|c|c|c|}
\hline Station & Mast 1 & Mast 2 & Mast 3 & Mast 4 \\
\hline \hline Distance to coast [km] & 0.08 & 1.2 & 4.4 & 30.2 \\
\hline Height of mast [m] & 32 & 24 & 24 & 24 \\
\hline Wind speed & 6 & 3 & 3 & 6 \\
\hline Wind direction & 2 & 2 & 2 & 2 \\
\hline Gust wind speed & 1 & 1 & 1 & 1 \\
\hline Temperature & 2 & 2 & 2 & 2 \\
\hline Temperature gradient & 4 & 2 & 2 & 4 \\
\hline Relative humidity & 3 & 1 & 1 & 3 \\
\hline Precipitation & & & 1 & \\
\hline Atmospheric pressure & 1 & & & 1 \\
\hline Incoming short-wave & 1 & & 1 & \\
\hline Sonic anemometer & & & 1 & \\
\hline
\end{tabular}

used here wind speed was recorded as 10 -min average values while wind direction and temperature were recorded as instantaneous values, although the response time of the instruments themselves provided some smoothing. The time constants of the wind vanes are about $20 / u[\mathrm{~m} / \mathrm{s}]$ while the thermometers had time constants of around two minutes (Mahrt and Larsen, 1982).

\subsection{Data selection and analysis}

The present study is concerned with the change of wind speed as the air moves inland from the sea under near-neutral conditions. Therefore, data were included in the study only if:

- the wind came from a $90^{\circ}$ westerly sector at mast 1 ,

- data were available at all four masts,

- the wind speed was larger than $12 \mathrm{~m} / \mathrm{s}$ at the top level of mast 1 while at the same time the absolute value of the Richardson number (at $z=10 \mathrm{~m}$ ) was less than 0.03 at all masts. 
The data set selected in this way consisted of 2048 sets of profile data recorded simultaneously along each mast, meaning that 2 per cent of the data fulfilled the above criteria. It was stratified subsequently according to the following criteria.

\section{Day or night}

2. Season: winter (December, January, and February spring (March, April, and May) summer (June, July, and August) fall (September, October, and November).

3. Finally, the $90^{\circ}$ direction sector was subdivided into nine $10^{\circ}$ sectors.

The day/night and seasonal criteria both stratified the data according to land-sea temperature differences (Larsen and Jensen, 1983) as well as land roughness, since the roughness of land varies with season following the vegetation and other aspects of the surface such as snow-cover and tilling.

The subdivision into $10^{\circ}$ direction sectors was made because it allowed us to determine fairly well-defined fetch conditions for each mast. The direction sector was determined on the basis of data from mast 1 . Figure 3 illustrates the direction sectors for mast 3 .

Between the velocity $u_{i}$ at mast $i(i=2,3,4)$ and the upstream over-water velocity $u_{1}$ the ratios were calculated for each record, all at the $24-\mathrm{m}$ level. Subsequently, the average values and standard deviations of these ratios were computed within each bin defined by the day/night, season and wind direction criteria given above.

As indicated above, the upstream wind was determined from mast 1 . Due to the presence of an approximately $100-\mathrm{m}$ wide rush field in front of mast 1 , we used the $31-\mathrm{m}$ wind (see Fig. 2) to estimate the over-water wind at the height of $24 \mathrm{~m}$. This was done using Charnock's relation in conjunction with a logarithmic wind profile.

$$
\begin{aligned}
u_{*} & =\kappa u_{31} / \ln \left(31 / z_{0 w}\right) \\
z_{0 w} & =c u_{*}^{2} / g \text { with } c=1.4 \times 10^{-2} \\
u_{24} & =\frac{u_{*}}{\kappa} \ln \left(24 / z_{0 w}\right)
\end{aligned}
$$




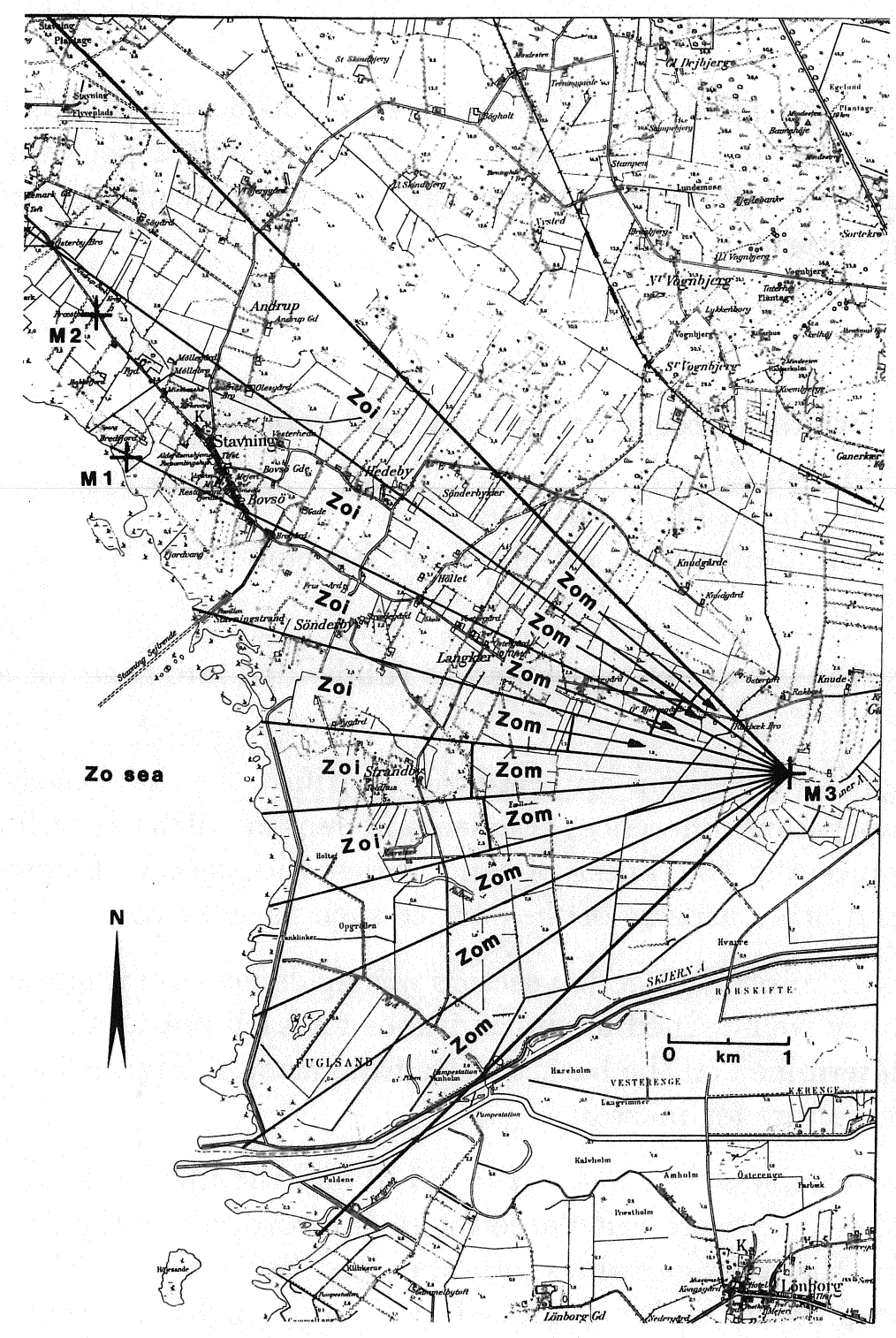

Figure 3: Layout of the nine westerly direction sectors from each mast, here mast 3. Also shown in the figure is how different roughness values are ascribed to different areas for use in the model computations. $z_{0 m^{-}}$ values are estimated from the profile measurements, while the $z_{0 i}$-values are estimated as described in the text. Many of the $z_{0 i}$-areas in the figure are further subdivided into areas with different $z_{0 i}$. For simplicity this is omitted in the figure. 


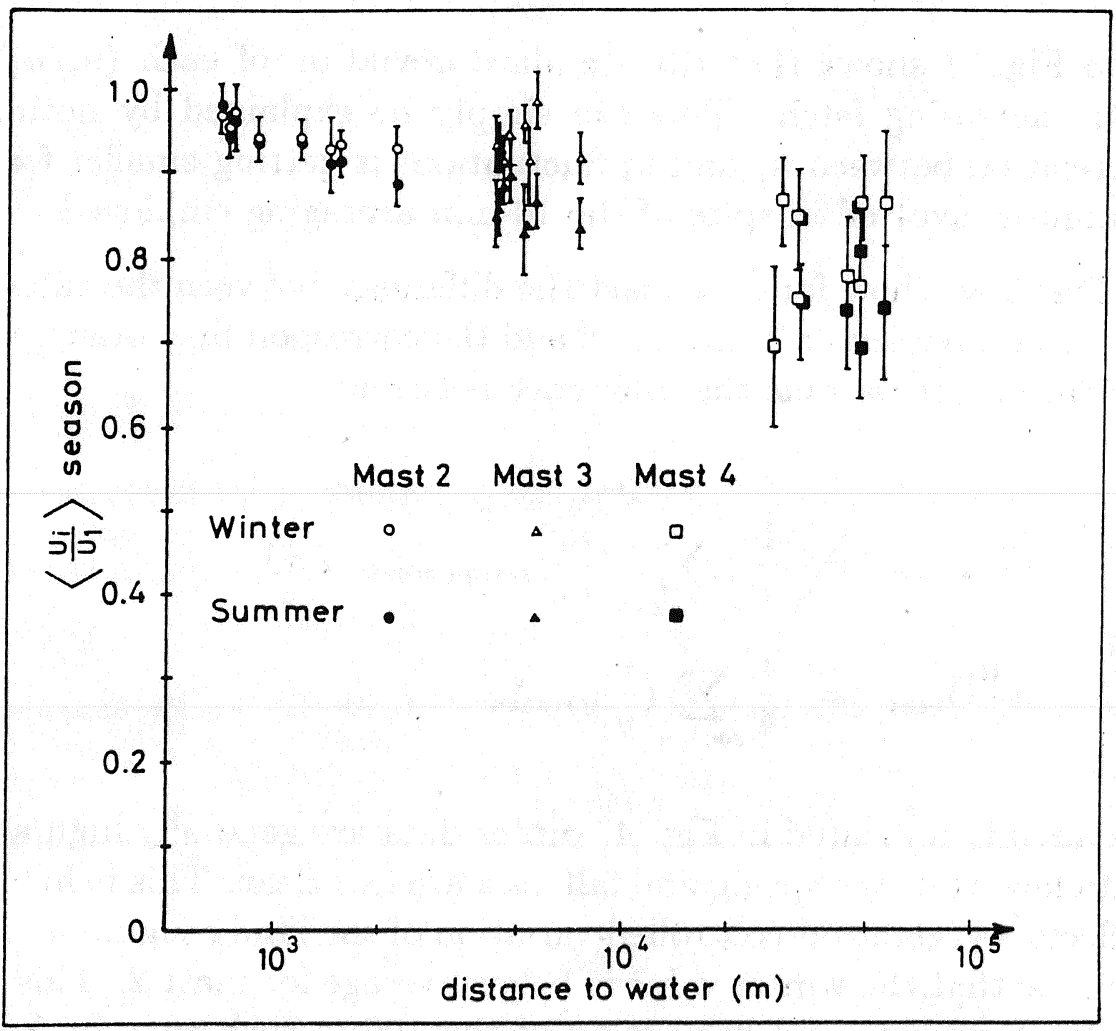

Figure 4: The figure shows $\left\langle u_{i} / u_{1}\right\rangle$, where $u_{i}$ is the velocity at a height of $24 \mathrm{~m}$ at mast $i$ and the averaging pertains to sectors and seasons. The ratio is plotted versus distance to the water (see Appendix A) for each mast. Only the ratios for winter and summer seasons are shown. The bars indicate the standard deviation on the estimated $\left\langle u_{i} / u_{1}\right\rangle$.

Initial computations of the average velocity ratios within bins showed no significant difference between night and day bins, lending some credibility to our neglect of thermal effects. Therefore, we consider below only data stratified according to season and sectors.

The distance to the water from each mast is summarized for each sector in Appendix A. Having determined these distances, the sector and seasonal averages of $u_{i} / u_{1}$, and the corresponding standard deviations can be plotted versus land fetch. This is done in Fig. 4 for the winter and summer data.

The velocity ratio is generally seen to decrease with increasing fetches. However, there is considerable scatter. This reflects that plotting $\left\langle u_{i} / u_{1}\right\rangle$ versus fetch only, is a strong idealization. In reality, the velocity at each mast reflects the upstream history of the flow, and with few exceptions a trajectory passing one mast will not pass any of the others. 
Also Fig. 4 shows that the standard deviation of each $\left\langle u_{i} / u_{1}\right\rangle$ increases with increasing fetch. This can simply be explained by noting that the correlation between $u_{1}$ and $u_{i}$ fluctuations is getting smaller for the larger distances involved in spite of the 10 -min averaging employed.

In Fig. 5 we show for each mast the difference between the value of $\left\langle u_{i} / u_{1}\right\rangle$ averaged over sector 2 through 8 and the corresponding annual average, i.e. for each mast we take the difference between

$$
\begin{aligned}
\left\langle\frac{u_{i}}{u_{1}}\right\rangle_{\text {season }} & =\frac{1}{7} \sum_{\text {sector } 2-8}\left\langle\frac{u_{i}}{u_{1}}\right\rangle_{\text {season }, \text { sector }} \text { and } \\
\left\langle\frac{u_{i}}{u_{1}}\right\rangle_{\text {year }} & =\frac{1}{4} \sum_{\text {season }}\left\langle\frac{u_{i}}{u_{1}}\right\rangle_{\text {season }}
\end{aligned}
$$

As already indicated in Fig. 4, winter data are generally high and summer data low while the spring and fall data are less clear. This behaviour mostly reflects a vegetation-controlled variation of the land roughness. As a detail, we note that the winter value is below average for mast 2 . This reflects the cycle of growing and harvesting of the $100-\mathrm{m}$ rush zone in front of mast 1. This zone is harvested at the end of February and in the beginning of March. The rush grows to a height of about two metres in late summer and remains at this height during winter. This rush zone does not influence the $31-\mathrm{m}$ velocity at mast 1 (at least not for sectors $2-8$ ), but it certainly influences the velocity at mast 2 , being $1 \mathrm{~km}$ downwind from this zone.

\subsection{Model description}

For comparison with the data, we summarize here a simple model for the flow response to step changes in surface roughness. Its basic idea is due to M. Miyake (Panofsky (1973), Businger (1974) and Jensen (1978)).

When the flow passes a change in surface roughness, an internal boundary layer grows as

$$
\frac{\partial h}{\partial x}=A \cdot \frac{\sigma_{w}(h)}{u(h)}
$$

in which $h$ is the height of the internal boundary layer, $x$ is the fetch downwind of the roughness change, while $u$ is the mean speed and $\sigma_{w}$ the standard deviation of the vertical wind speed. The two last parameters are described by 


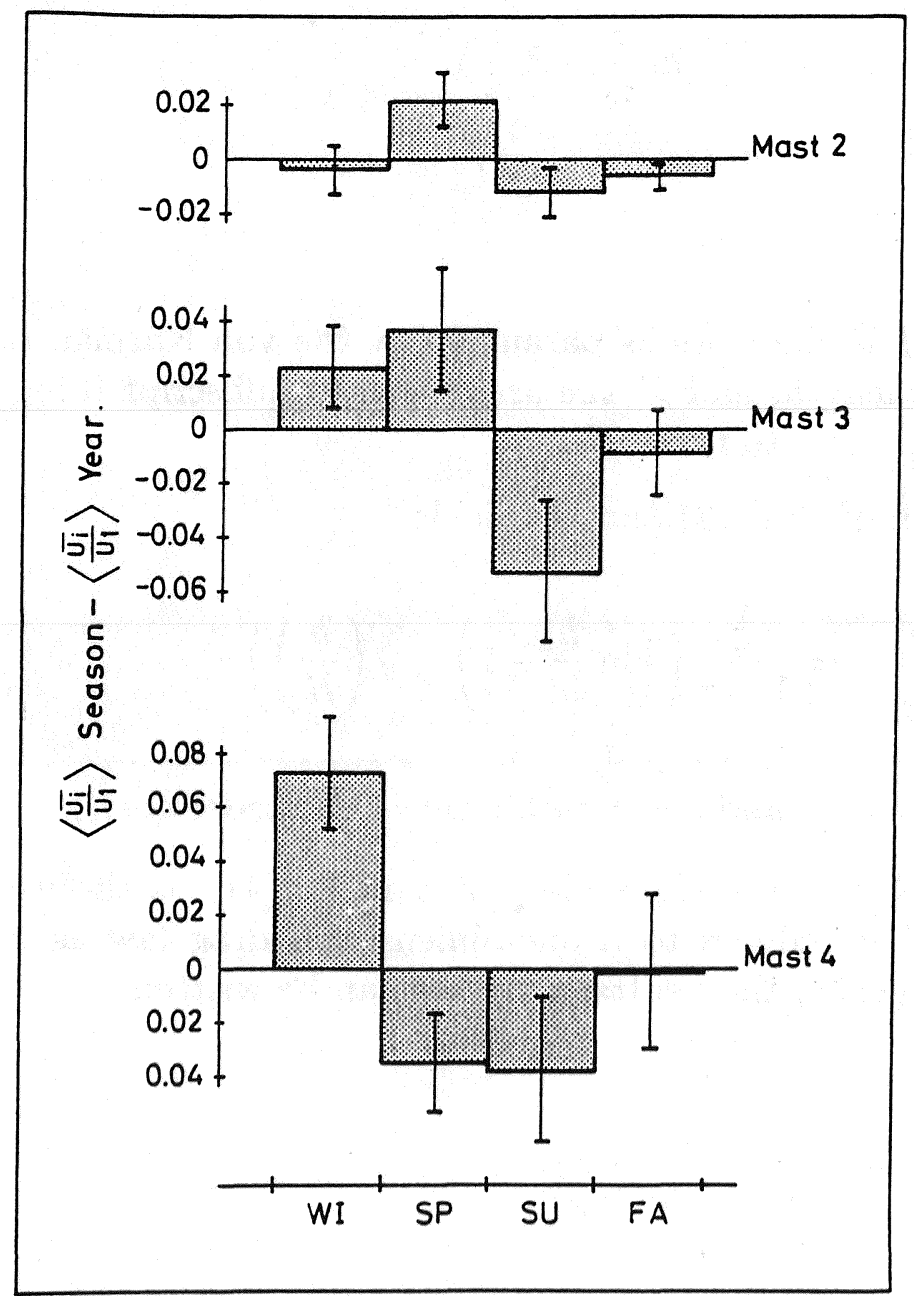

Figure 5: Seasonal variation of $\left\langle u_{i} / u_{1}\right\rangle$ averaged over sectors 2-8 (see (2)) for the different masts. The bars indicate standard deviation on sector average shown by overbar of $\left\langle u_{i} / u_{1}\right\rangle$. The figure shows that the winter data seem to lie above the summer data, reflecting, we believe, a generally higher land roughness during the summer. 


$$
\begin{aligned}
u & =\frac{u_{* 0}}{\kappa}\left(\ln \frac{z}{z_{0}}-2 \frac{z}{H}\right) \\
\sigma_{w} / u_{* 0} & =\sigma_{w 0} / u_{* 0}\left(1-\frac{z}{H}\right)^{2} \\
H & =u_{* 0} / f
\end{aligned}
$$

in which $f$ is the Coriolis parameter, $\kappa$ the von Kármán constant, $z_{0}$ the roughness length, and $H$ the scale height. Subscript 0 indicates that the parameter refers to the surface.

Integration of Eqs. (3) and (4) yields

$$
c \frac{x}{z_{0}}-1=\frac{\frac{h}{z_{0}}}{1-z}\left(\left(\ln \frac{h}{z_{0}}-1\right)-y\left(\frac{h}{H}\right)\right)
$$

with $y\left(\frac{h}{H}\right) \sim \frac{h}{H}$ and $c$ is a coefficient of the order one.

For $z / H<<1$, the expression for $u$ in Eq.(4) has the usual logarithmic form, and it reduces to a one-dimensional drag law as $z \rightarrow H$. From Tennekes (1973) the neutral drag law can be written

$$
\begin{aligned}
U_{G} & =\frac{u_{* 0}}{\kappa}\left(\ln \frac{H}{z_{0}}-2\right) \\
V_{G} & =-12 u_{* 0} \\
G^{2} & =U_{G}^{2}+V_{G}^{2}
\end{aligned}
$$

where $G$ is the geostrophic wind and $U_{G}, V_{G}$ its components in a coordinate system aligned with the surface wind.

A transition from a smooth to a rough surface is depicted in Fig. 6. By matching the upstream wind profile $u_{1}(z)$ and the downwind profile $u_{2}(z)$ at $h(x)$, we obtain for $h \leq H_{1}$ (Zone I in Fig. 6)

$$
\frac{u_{* 02}}{u_{* 01}}=\frac{\ln \frac{h}{z_{01}}-2 \frac{h}{H_{1}}}{\ln \frac{h}{z_{02}}-2 \frac{h}{H_{2}}}
$$

and for $h \geq H_{2}$ (Zone II in Fig. 6)

$$
\frac{u_{* 02}}{u_{* 01}}=\frac{\ln \frac{H_{1}}{z_{01}}-2}{\ln \frac{h}{z_{02}}-2 \frac{h}{H_{2}}}
$$




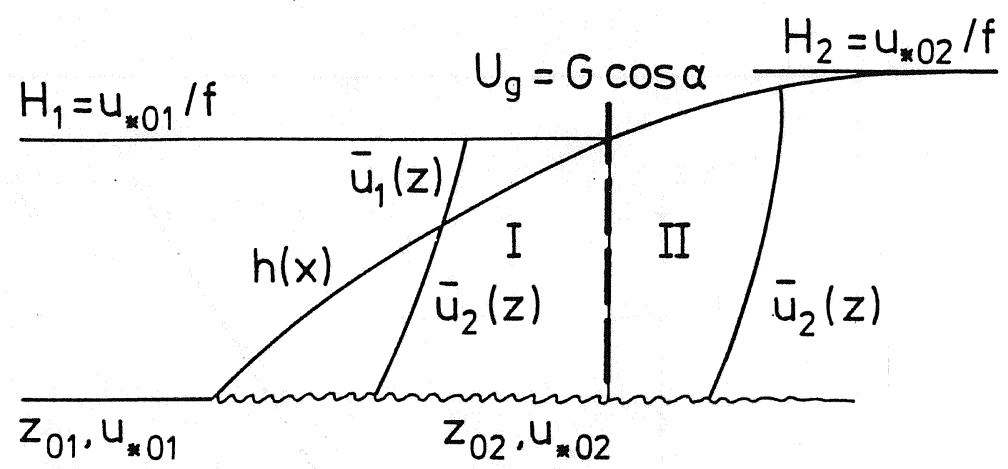

Figure 6: Growth of an internal boundary layer (IBL) in a two-dimensional planetary boundary layer (PBL) for smooth-to-rough transition. In Zone I the IBL grows within the smooth PBL, while in Zone II $h(x)$ is above the smooth PBL (Larsen et al., 1982).

in which it is assumed that both profiles are described by equilibrium expressions as Eq. (4).

Assuming $\frac{h}{H} \rightarrow 0$ in the above equations, we recover the surface layer expressions suggested by Miyake, corresponding to Eqs. (4) and (7)

$$
\begin{aligned}
& c \frac{x}{z_{0}}-1=\frac{h}{z_{0}}\left(\ln \frac{h}{z_{0}}-1\right) \\
& \frac{u_{* 02}}{u_{* 01}}=\frac{\ln \frac{h}{z_{01}}}{\ln \frac{h}{z_{02}}}
\end{aligned}
$$

The coefficient $c$ in Eqs. (5) and (9) can be calibrated by comparison with measured stress ratios. Here, we follow Larsen et al. (1982) in using $c=0.9$.

As the IBL grows, the surface wind must turn to approach the drag law, Eq. (6), for the new equilibrium boundary layer. Larsen et al. (1982) suggest to take this into account by interpolating the cross-isobaric angle, $\alpha$, as

$$
\sin \alpha=\frac{V_{G}}{G}= \begin{cases}-12 H_{1} f / G & \text { for } h \leq H_{1} \\ -12 h f / G & \text { for } \quad H_{1}<h \leq H_{2}\end{cases}
$$




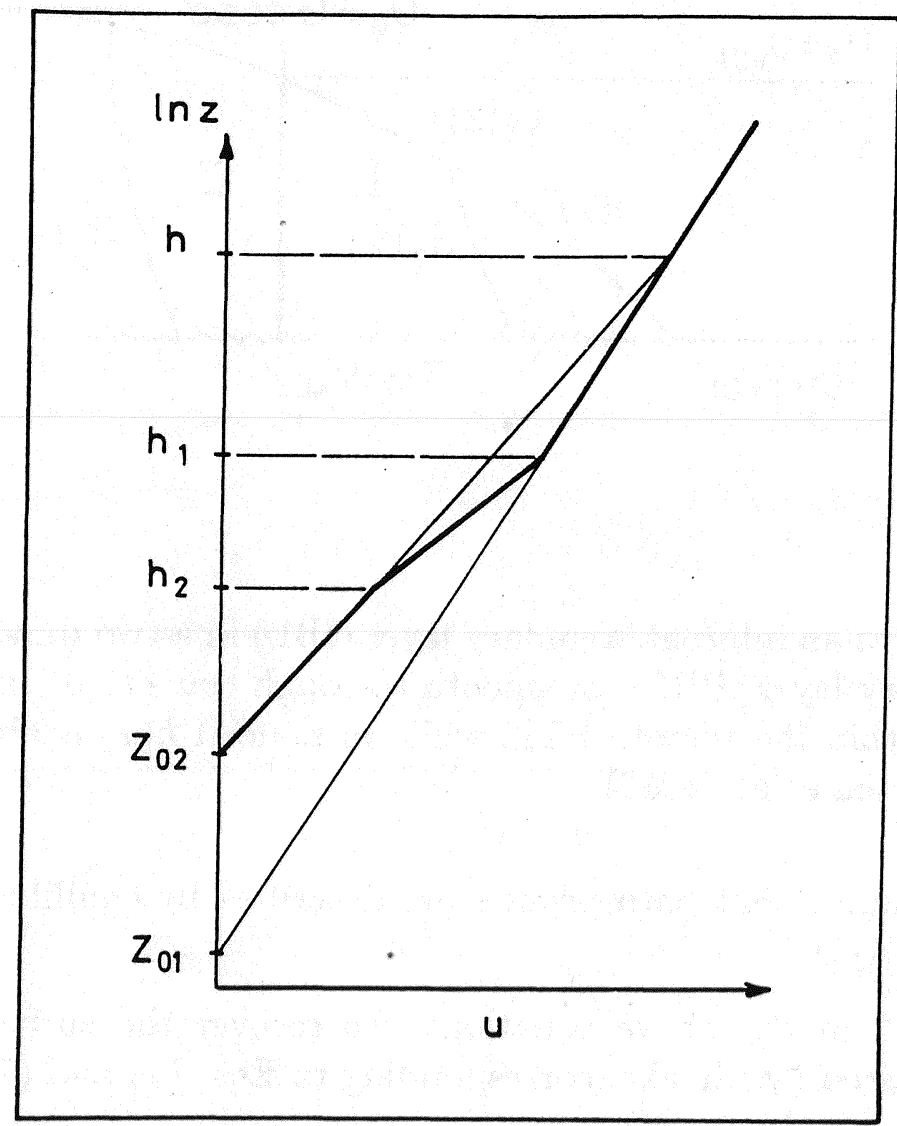

Figure 7: Behaviour of the velocity profile in an internal boundary layer (here for a smooth-to-rough-transition according to Jensen and Peterson, 1977). The outer and inner profiles (thin lines) are matched at $z=h$. The profile in equilibrium with the surface stress of the IBL reaches up to $z=h_{2}$ ( $\sim$ between $\frac{1}{10}$ and $\frac{1}{20}$ of $h$ ). The outer profile reaches down to $h_{1} \sim \frac{1}{3} h$. For $h_{2}<h<h_{1}$ the profile is interpolated. For rough to smooth transition the kink reverses. 
and rewrite Eq. (8) as

$$
\frac{u_{* 02}}{u_{* 01}}=\frac{\cos \alpha}{\cos \alpha_{1}} \frac{\left(\ln \frac{H_{1}}{z_{01}}-2\right)}{\left(\ln \frac{h}{z_{02}}-2 \frac{h}{H}\right)}
$$

where $\alpha_{1}$ pertains to the upstream surface.

So far the discussions have been concerned with the smooth to rough transition. This transition is characterised by a more turbulent IBL growing through a less turbulent planetary boundary layer. The rough to smooth transition, on the other hand, is characterised by a dying of the turbulence in the more turbulent PBL to make room for the growth of the less turbulent IBL. Hence, the physics is quite different. However, it is found that the surface layer model, Eq. (9), describes both types of transitions quite well provided that the $z_{0}$-value used in the equation for $h(x)$ is the one pertaining to the rougher surface (Panofsky (1973), Jensen (1978)). Larsen et al. (1982) suggest use of the same rule for the extended model in Eq. (5) in which both $z_{0}$ and $H$ now must pertain to the rougher surface and to stop the growth of $h$ when reaching the scale height $H_{2}$, that for the rough to smooth transition is smaller than $H_{1}$.

As formulated above, the model predicts the stress ratios. To predict the corresponding wind speed ratios, Larsen et al. (1982) used the equilibrium profiles

$$
\frac{u_{2}(z)}{u_{1}(z)}=\frac{u_{* 02}}{u_{* 01}} \frac{\ln \frac{z}{z_{02}}-2 \frac{z}{H_{2}}}{\ln \frac{z}{z_{01}}-2 \frac{z}{H_{1}}}
$$

where the $u_{*}$-ratio is given by Eqs. (7) and (11).

However, we shall employ here an idea by Jensen and Peterson (1977). From comparison with experimental data and numerical models by $\mathrm{Pe}-$ terson (1972), Taylor (1969) and Rao et al. (1974), they concluded that the profiles could be best described by the model shown in Fig. 7 for the smooth-to-rough transition. Here, the $u_{*}$ ratio is still found by matching the equilibrium profiles at $z=h(x)$. However, the outer profile is found to extend down to $z=h_{1} \sim \frac{1}{3} h(x)$, while the inner profile being in equilibrium with $u_{* 02}$ extends up to $z=h_{2} \sim 0.1 h(x)$. In between $h_{1}$ and $h_{2}$ we shall simply interpolate linearly, i.e.

$$
u(z)=u\left(h_{2}\right)+\left(u\left(h_{1}\right)-u\left(h_{2}\right)\right) \frac{\ln z-\ln h_{2}}{\ln h_{1}-\ln h_{2}} .
$$


For use in situations with several roughness changes the above model formulations are applied as follows (Larsen et al., 1982, Petersen and Troen, 1986)

$$
u_{n} / u_{0}=\Pi_{i=0}^{n-1} u_{i+1}\left(x_{i+1}\right) / u_{i}\left(x_{i}\right),
$$

in which $x_{i}$ is the distance between the point where $u_{i}$ is estimated and the location of roughness change $i$, considering $u_{0}$ as an equilibrium upstream condition.

In the next sections we shall compare the JYLEX data with aspects of the above model construction. Therefore, it seems reasonable with a short discussion of what is known about its validity.

For short fetches, say $x<100 \mathrm{~m}$, the surface layer description in Eq. (9) is known to be the most successful of all models available in describing the surface stress ratio (Jensen, 1978, Larsen et al. 1982).

The extended model Eq. (5) through Eq. (12) may be better for slightly larger fetches as long as growth of the IBL remains controlled by diffusion, because it allows for a decrease of the turbulence level with height. However, it does not contain any of the physics involved when the fetches approach the Ekman length $G / f$ for which pressure and Coriolis forces will be responsible for the final approach to equilibrium. The model was tested by Hedegaard and Larsen (1982) on climatological data, and it was concluded that the model tended to approach equilibrium too slowly, but that it worked reasonably well out to fetches of the order of $30-40 \mathrm{~km}$. However, the comparison with data was made uncertain by the uncertainty of estimating the surface roughness for extended areas, a problem we will have to face also in the present paper. As far as we know the shape of the profile shown in Fig. 7 has not been much used in connection with the type of model described here. However, the different numerical models with second-order turbulence closure are all quite consistent in predicting this kind of shape.

\subsection{Determination of the surface roughness}

To compare the model prediction with measurements, the roughness environment must be determined for each mast in each of the nine sectors considered. This involves for each sector and mast a determination of the distance from the mast to each roughness change as well as the values of relevant roughness lengths. The method is illustrated in Fig. 3, and details of the roughness determination are described in Appendix A in which are also shown the actual values used. 
The fetches to each roughness change were determined from maps as well as from inspection of the area. Here, the first change in front of a mast was best defined because a mast was typically placed on the eastern side of a field to obtain a maximum homogeneous and unobstructed fetch for westerly flows. The roughness of this near field was also quite well determined, since it was found from velocity profiles of the data set to be compared with model predictions.

As regards the areas further away from the masts, both fetches and roughness values became less well defined. We used the methods recommended in Jensen et al. (1984) and Petersen and Troen (1986). The roughness values thus determined deviate from the near-field roughness in several ways. Since the near-field roughnesses are measured data, they follow the cycles of vegetation and tilling for each particular site. Hence, different $z_{0}$-values are used in different seasons (see tables in Appendix A). This is not so for the large-scale roughness values. They generally pertain to types of terrain with a mixed combination of roughness elements, i.e. fields, houses, trees and hedges. How the roughness of such areas will vary with season, if at all, is not well-known.

For the upstream water roughness we use Charnock's relation described in Eq. (1), where the coefficient cited, $c \sim 1.4 \times 10^{-2}$ is estimated mostly from data pertaining to the open ocean, which obviously are different from the upstream conditions needed here. Therefore, we have tested the model performance for various values of $c$, as will be discussed below.

\subsection{Comparison between model and data}

The models described in Section 4 have been used to compute $u_{i} / u_{1}$ for $z=24 \mathrm{~m}$ for each sector, mast and season. The computed $u_{i} / u_{1}$ are compared with the corresponding $\left\langle u_{i} / u_{1}\right\rangle$ values obtained from the data set as discussed in the first sections of this paper.

For the detailed comparison, we define the relative deviation as

$$
\delta=100 \cdot\left(\left\langle\frac{u_{i}}{u_{1}}\right\rangle_{e x p}-\left(\frac{u_{i}}{u_{1}}\right)_{c o m p}\right) /\left\langle\frac{u_{i}}{u_{1}}\right\rangle_{\exp }
$$

where $\delta$ now is defined for each of the masts, sectors and seasons.

As discussed in the preceding section, the estimate of the roughness surroundings for each mast is associated with quite some uncertainty. Therefore, we cannot test in a strict sense the absolute validity of the model approaches considered. Instead we will address the following questions: 
Table 2: The effect on $\delta[\%]$ in Eq. (15) of changing Charnock's constant in the formula for the upstream water roughness. $\bar{\delta}$ is the average of $\delta$ over sectors $2-8, \sigma$ is the corresponding standard deviation.

\begin{tabular}{|l|rrrrrr|c|}
\hline Season & $\bar{\delta} M_{2}$ & $\sigma M_{2}$ & $\bar{\delta} M_{3}$ & $\sigma M_{3}$ & $\bar{\delta} M_{4}$ & $\sigma M_{4}$ & $c$ \\
& & & & & & & \\
\hline winter & 0.9 & 1.2 & 3.1 & 2.0 & 12.8 & 2.8 & $0.5 \times 10^{-2}$ \\
spring & 2.2 & 1.1 & 5.8 & 2.7 & 0.8 & 2.8 & \\
summer & 2.0 & 1.6 & 4.1 & 4.0 & -2.3 & 5.7 & \\
fall & 2.1 & 1.3 & 3.7 & 2.5 & 5.1 & 2.4 & \\
year & 1.8 & & 4.2 & & 5.3 & & \\
\hline winter & -0.2 & 0.9 & 0.7 & 2.0 & 10.0 & 2.9 & $1.4 \times 10^{-2}$ \\
spring & 1.4 & 1.1 & 3.7 & 2.9 & -2.2 & 2.8 & \\
summer & 1.1 & 1.5 & 2.1 & 4.0 & -1.0 & 5.3 & \\
fall & 1.1 & 1.0 & 1.5 & 2.5 & 2.2 & 2.5 & \\
year & 0.9 & & 2.0 & & 2.3 & & \\
\hline winter & -1.7 & 0.7 & -2.6 & 1.9 & 6.0 & 3.0 & $4.2 \times 10^{-2}$ \\
spring & 0.2 & 1.5 & 0.7 & 3.11 & -6.4 & 2.9 & \\
summer & -0.1 & 1.5 & -0.8 & 4.0 & -4.9 & 5.5 & \\
fall & -0.3 & 1.0 & 1.6 & 1.7 & -1.9 & 4.3 & \\
year & -0.5 & & -1.1 & & -1.8 & & \\
\hline
\end{tabular}

a) How will $\delta$ change with a changing estimate of the water roughness?

b) What is the influence on $\delta$ using the extended BL model rather than the surface layer model given by Eq. (9)?

c) How does introduction of the kinky profile in Fig. 7 influence $\delta$ ?

As a basic model we choose the extended BL model given by Eqs. (5) and (6). The kinky profile is used with $h_{1}=h / 3$ and $h_{2}=h / 15$. The upstream water roughness is determined by Charnock's constant $c \sim 1.4 \times 10^{-2}$. Tables 2, 3 and 4 illustrate how $\delta$ changes when we change one of the aspects considered under questions a) to c) in turn, keeping the other model characteristics as in the basic model.

For evaluation of the results in the tables we average $\delta$ over sectors 2-8 for each mast and season. (For reasons discussed in Appendix A we do not include sectors 1 and 9 in the averaging as these sectors were neglected also in the compilation of Fig. 5). The averaged $\delta$ is denoted $\bar{\delta}$. 
Table 3: The effect on $\delta[\%]$ (Eq. (15)) of changing the value of $h_{1}$, (Fig. 7). $\bar{\delta}$ is the average of $\delta$ over sectors $2-8$, and $\sigma$ is the corresponding standard deviation.

\begin{tabular}{|l|rrrrrr|l|}
\hline Season & \multicolumn{1}{|c}{$\delta M_{2}$} & $\sigma M_{2}$ & $\delta M_{3}$ & $\sigma M_{3}$ & $\delta M_{4}$ & $\sigma M_{4}$ & $h_{1}$ \\
\hline winter & -0.2 & 0.9 & 0.7 & 2.0 & 10.0 & 2.9 & $\frac{1}{3} h$ \\
spring & 1.4 & 1.1 & 3.1 & 2.9 & -2.2 & 2.8 & \\
summer & 1.1 & 1.5 & 2.1 & 4.0 & -1.0 & 5.3 & \\
fall & 1.1 & 1.0 & 1.5 & 2.5 & 2.2 & 2.4 & \\
year & 0.9 & & 2.0 & & 2.3 & & \\
\hline winter & -0.0 & 0.6 & 0.2 & 1.5 & 7.4 & 2.9 & $\frac{1}{2} h$ \\
spring & 2.2 & 1.5 & 3.2 & 3.2 & -5.1 & 2.7 & \\
summer & 2.9 & 1.5 & 1.9 & 3.9 & -3.5 & 5.3 & \\
fall & 2.1 & 0.8 & 1.1 & 2.2 & -0.2 & 3.4 & \\
year & 1.8 & & 1.6 & & -0.3 & & \\
\hline winter & 0.3 & 0.8 & -0.2 & 1.3 & 4.9 & 3.0 & $h$ \\
spring & 3.1 & 2.1 & 2.8 & 3.6 & -8.0 & 2.7 & \\
summer & 4.8 & 2.0 & 1.7 & 3.9 & -5.8 & 5.2 & \\
fall & 3.1 & 1.2 & 0.8 & 2.1 & -2.6 & 4.1 & \\
year & 2.8 & & 1.2 & & -2.9 & & \\
\hline
\end{tabular}

First, we study the influence of changing Charnock's constant. The results are summarized in Table 2. The $c$-value producing $\bar{\delta}$ close to zero for all three masts is seen to be between $1.4 \times 10^{-2}$ and $4.2 \times 10^{-2}$ around $c \sim 3 \times 10^{-2}$. This value is somewhat larger than the "normal" value $1.4 \times 10^{-2}$. However, the nearest part of the upstream conditions is either the shallow fjord or the coastal water (see Fig. 1). It is therefore not surprising to find $z_{0}$ somewhat larger than the "open-ocean" value (see e.g. Geernaert et al., 1987) who report corresponding $z_{0}$-values for the North Sea.

Next we shall study the influence on $\delta$ of changing the height, $h_{1}$, down to which the outer profile is supposed to describe the resulting profile (see Fig. 7). The effect of increasing this height to $h / 2$ and $h$ is shown in Table 4 , and as can be seen tendencies are different at the different masts. The reason is that the response to changing $h_{1}$ will depend on the number and character of the roughness changes experienced by the flow on its way to the measuring mast, as well as of the measuring height. 
Table 4: The effect on $\delta$ [\%] (Eq. (15)) of changing model behaviour for large fetches.

\begin{tabular}{|l|rrrrrr|c|}
\hline Season & $\bar{\delta} M_{2}$ & $\sigma M_{2}$ & $\bar{\delta} M_{3}$ & $\sigma M_{3}$ & $\bar{\delta} M_{4}$ & $\sigma M_{4}$ & IBL growth \\
& & & & & & & \\
\hline winter & -0.2 & 0.9 & 0.7 & 2.0 & 10.0 & 2.9 & $h \rightarrow H$ \\
spring & 1.4 & 1.1 & 3.1 & 2.9 & -2.2 & 2.8 & as \\
summer & 1.1 & 1.5 & 2.1 & 4.0 & 1.0 & 5.3 & $x \rightarrow \infty$ \\
fall & 1.1 & 1.0 & 1.5 & 2.5 & 2.2 & 2.4 & \\
year & 0.9 & & 2.0 & & 2.3 & & \\
\hline winter & -0.2 & 0.9 & 0.8 & 2.0 & 11.4 & 3.0 & \\
spring & 1.5 & 1.1 & 3.8 & 2.9 & -0.3 & 2.9 & $h \rightarrow \infty$ \\
summer & 1.3 & 1.5 & 2.5 & 4.0 & 1.2 & 5.3 & as \\
fall & 1.2 & 1.0 & 1.7 & 2.5 & 4.0 & 2.7 & $x \rightarrow \infty$ \\
year & 1.0 & & 2.2 & & 4.1 & & \\
\hline winter & -0.2 & 0.9 & 0.7 & 2.0 & 14.2 & 3.0 & \\
spring & 1.5 & 1.1 & 3.1 & 2.9 & 2.4 & 3.4 & $h=H$ \\
summer & 1.3 & 1.5 & 2.1 & 4.0 & 3.3 & 6.2 & $x \geq 10 \mathrm{~km}$ \\
fall & 1.2 & 1.0 & 1.5 & 2.5 & 6.6 & 4.4 & \\
year & 1.0 & & 2.0 & & 6.6 & & \\
\hline
\end{tabular}

Finally, we study the importance of the model behaviour for large fetches. Table 4 shows the result. The first case is our basic model, next is the surface layer model described by Eq. (9) while in the last case we study the effect of forcing the internal boundary to equilibrium at a $10-\mathrm{km}$ fetch. The reason for this is that the two former models are unrealistic for large fetches. The surface layer model does not approach a new equilibrium at all, while this is the case for the extended model, however, for so long fetches that it seems unrealistic. It appears from Table 4 that the extended model fares best, however, only marginally better than the pure surface layer model.

The model in which the IBL is forced to equilibrium by forcing $h \rightarrow H$ when $x \geq 10 \mathrm{~km}$ seems to fare worst, indicating that more than $10 \mathrm{~km}$ is needed for an IBL to reach equilibrium. It is noteworthy that the $\sigma$-values in Tables 2-4 change very little from case to case. Only $\bar{\delta}$ seems to change, the only exception being the last case in which not only $\bar{\delta}$ is increased, but to some extent also $\sigma$ when forcing $h$ to $H$ for $x \geq 10 \mathrm{~km}$. Undoubtedly, this is due to the fact that we force an abrupt change into the model response when $x$ passes $10 \mathrm{~km}$. 
The seasonal variation of $\bar{\delta}$ is a common characteristic of the three tables. The magnitude of the variation is seen to be characteristic for each mast and quite independent of the different model characteristics and parameter values tested in the various tables.

Part of this variability is probably due to seasonal variability in the largerscale roughness, which is not taken into account in the model computations and therefore will show up in $\bar{\delta}$. It appears from the tables that the seasonal variability of $\bar{\delta}$ is most pronounced for mast 4. In Appendix A it is shown that mast 4 also is the mast for which we were forced to make the most extensive use of terrain-type assessment of the large-scale roughness. For this mast it is seen from the tables that $\bar{\delta}_{\text {winter }}>\bar{\delta}$ for the other seasons. Equation (15) suggests that this might be interpreted as if the large-scale roughness for mast 4 is smaller during winter than during the rest of the year, indicating that the large-scale roughness exhibits a seasonal variation as is found in the roughness for the fields close to the masts. However, the picture is not really clear as the table also show that the seasonal variation of $\bar{\delta}$ is opposite for masts 2 and 3 , although much weaker.

The seasonal variation found in $\delta$ can most simply be related to a seasonal variation in $z_{0}$ using the surface layer model and neglecting profile kinks. We simplify the description to only two roughnesses, $z_{01}$ pertaining to water and $z_{02}$ describing the land roughness.

For the surface layer model we find

$$
\frac{u_{2}(z)}{u_{1}(z)}=\frac{\ln \frac{h}{z_{01}}}{\ln \frac{h}{z_{02}}} \cdot \frac{\ln \frac{z}{z_{02}}}{\ln \frac{z}{z_{01}}}
$$

Differentiating Eq. (15) with respect to $\ln z_{02}$ and using (17), we find

$$
d \delta=-100 \frac{d u_{2}}{u_{2}}=100 \frac{\ln \frac{h}{z}}{\ln \frac{z}{z_{02}} \cdot \ln \frac{h}{z_{02}}} \frac{d z_{02}}{z_{02}}=100 a \frac{d z_{02}}{z_{02}}
$$

With average land fetches of the order of 45,7 and $2 \mathrm{~km}$ for masts 4,3 , and 2 , respectively, we have $a_{4} \sim 0.11, a_{3}=0.09$, and $a_{2}=0.06$ if we use $z=24 \mathrm{~m}$ and an overall $z_{02}$-value of $20 \mathrm{~cm}$. This value is realistic for the large-scale roughness associated with mast 4 . It is somewhat too high for the other masts, but the exact value for $z_{02}$ is not critical in Eq. (17).

From Tables 2,3 , or 4 is seen that for mast 4 the winter $\delta$-value is about 8 per cent larger than for the rest of the year. Since most of the roughness between mast 4 and the water is large-scale roughnesses (see Table 8), this 


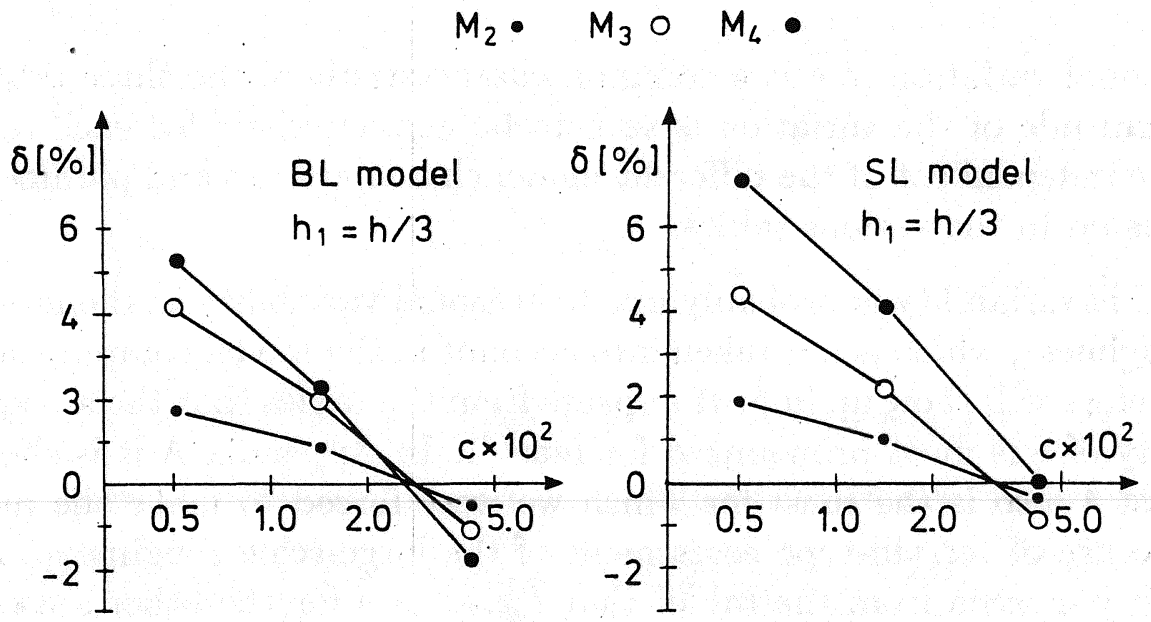

Figure 8: The variation with Charnock's constant, $c$, of the yearly mean values of $\bar{\delta}$ (see Eq. (15)) for the different masts based on both the full boundary layer model (BL) and the surface layer model (eq. (9)), denoted SL.

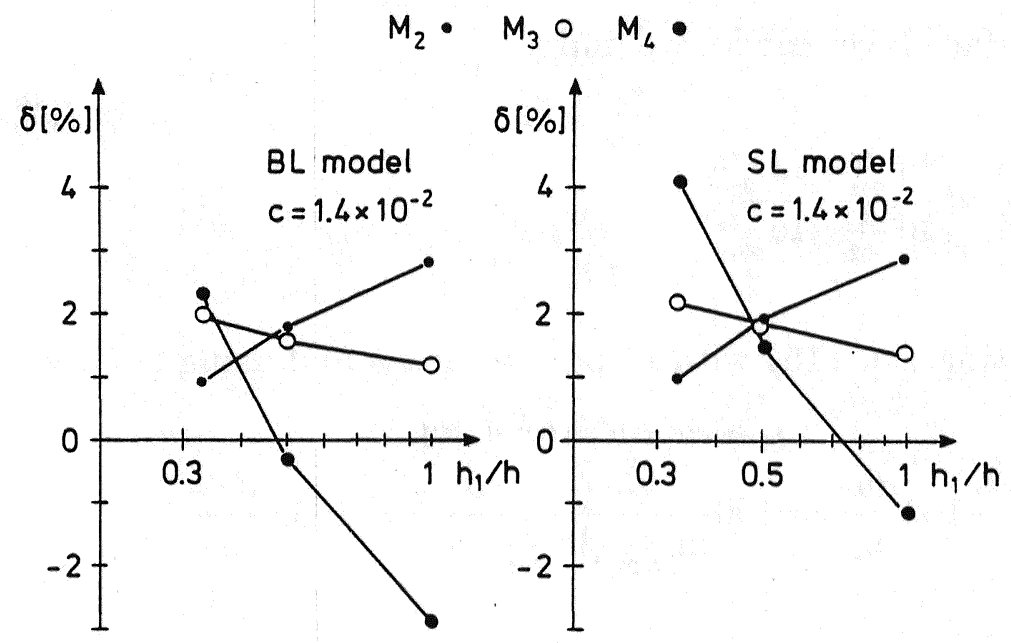

Figure 9: The variation of the yearly mean value of $\bar{\delta}$ (see Eq. (15)) versus the height ratio $h_{1} / h$ (compare Fig. 7) for the different masts and based on both the full boundary layer model (BL) and the surface layer model (SL). 
means through Eq. (17) that the estimated large-scale roughness is about 80 per cent too high during the winter season.

In Fig. 8 we have studied more closely the influence of the estimated upstream water roughness by plotting the yearly average $\delta$-values for different values of the Charnock constant for the three masts (compare Table 2). The influence of the Charnock constant is shown both using the extended BL model and the surface layer model (SL). From the figure is seen that the model-data comparison for all three masts is internally consistent in showing that $\bar{\delta} \sim 0$ for a Charnock constant around $3 \cdot 10^{-2}$, as already noted above. For the SL-model the $\bar{\delta}$-values at mast 4 look slightly less consistent with those for the two other masts than they do for the BLmodel. However, using Eq. (17), it is seen that a 15 per cent reduction of the large-scale roughness values would reverse the picture.

Finally, in Fig. 9 we have studied the influence on $\delta$, using different $h_{1}$ values both for the BL- and the SL-model (compare Fig. 7 and Table 3). The figure indicates that a kinky profile with $h_{1} / h$ between $\frac{1}{3}$ and $\frac{1}{2}$ is superior to using $h_{1} / h=1$, in the sense that by changing Charnock's constant in the first case we can force $\delta \sim 0$ simultaneously for all masts, while this is clearly not possible for $h_{1} / h \sim 1$, compare e.g. with Eq. (17).

\subsection{Conclusion and discussion}

In our study we have found that the uncertainty of the roughness and fetch values not directly measured, made any absolute comparison of model and data impossible. With this uncertainty in mind, we conclude that comparison between models and data indicates that both the simple surface layer model and the extended form discussed here perform reasonably well for the entire fetch interval. This is true despite the essential incorrectness of both models for large fetches where they either do not approach a new equilibrium situation or approach it too slowly.

The comparison between models and data indicate that the upstream water roughness should be somewhat larger than indicated by open-ocean data, fitting However, the optimum value found by us fits quite well with data from measurements in the nearby German Bight by Geenaert et al. (1987), who argue for physical reasons as well that the water closer to the shore should be rougher than the open ocean.

We have illustrated the seasonal variation of the surface roughness over land. From the measurements we conclude that the land has an overall higher roughness during summer than winter. For fields close to the measuring masts we are able to follow the seasonal variation of roughness. By 
means of photographs we were able to see how this roughness follows the growth cycle of the crop, and we found that in the growing season the profile roughness closely matches well-known formulas that related $z_{0}$ to the height of vegetation (see e.g. Thom, 1971 and Brutsaert, 1975).

\subsection{Appendix A}

\subsubsection{Roughness and fetch conditions at the four masts}

The determination of the relevant fetches for each mast has been a hybrid enterprise involving maps, inspection trips, photographs and measured velocity profiles.

As the situation becomes more and more ambiguous as we move inland, we shall start discussing mast 1 . This mast looks over the water of Ringkøbing Fjord which is separated from the North Sea about $10 \mathrm{~km}$ to the west by a narrow $(\sim 400 \mathrm{~m})$ isthmus (see Fig. 1$)$. In the following we shall neglect this isthmus in general and consider the fjord and North Sea to be one uniform water surface with a roughness $z_{\text {ow }}$, given by Eq. (1).

Between the water and mast 1 is a narrow belt of rush which after harvesting in late winter/early spring grows until slightly less than $2 \mathrm{~m}$ by the end of the summer and remains so until next harvesting. The roughness of this rush was determined by the data in sector 9 which was the only sector with sufficient rush fetch to allow the profile method to be used for determining the displacement length $d$ and roughness $z_{0}$. The roughness found was then taken as the proper value for the other sectors as well. The $d$ and $z_{0}$ values found were in accordance with the generally accepted relations between height of vegetation, $d$ and $z_{0}$ for this kind of vegetation (see e.g. Thom, 1971). The rush fetch was evaluated from maps and inspections to the site. The resulting list of fetches and roughnesses are as shown in Table 6. It is seen that the influence of the rush surface will not reach the $31-\mathrm{m}$ level, which is the level used to infer the upstream over-water condition, except for perhaps sector 9 . Therefore, this sector was dropped in the study involving the comparison between data and the different models.

Mast 2 is placed on the eastern side of a field bordering the rush roughly $800 \mathrm{~m}$ to the west of the mast. For most sections, therefore, the roughness and fetch conditions for mast 2 are easy to determine: the field roughness is found by the profile method described above while the roughness of the rush was found in connection with mast 1 . For mast 2 we are accordingly able to describe most roughness values of interest as a function of season. Only for sectors 8 and 9 do we have to describe the roughness of mixed 
areas (fields, hedges, trees, and houses). For these sectors, therefore, we used only one roughness for the entire year for the large-scale fetches.

The roughness and fetch description for mast 2 is presented in Table 6.

Table 7 contains the roughness and fetch descriptions used for mast 3 . The near-field roughness is again determined from the profiles, and the seasonal variation is seen to reflect much the same crop pattern as for mast 2. For the large-scale roughness areas we used the $z_{0}$-values after ESDU (1972) (Jensen et al., 1984).

In connection with this mast, it was found that sector 1 followed the south coast of the fjord in such a way that the sectors for these fetches are half water and mud and rush fields and half land (see also Fig. 3). As we were unable to give a good roughness description for this combination we have neglected this sector in the data compilation.

Finally, we show the fetch and roughness conditions at mast 4 in Table 8. For the near-field roughness the seasonal variation is different from the patterns at the other masts. This reflects differences in vegetation. At mast 4 the field was laid down to grass. 
Table 5: Roughness lengths and fetches of the flow directions considered for mast 1. $z_{0 w}$ is the upstream water roughness computed from Eq. (1).

\begin{tabular}{|c|c|c|c|c|c|}
\hline Sector & $\begin{array}{c}\text { Direction } \\
{\left[{ }^{\circ}\right]}\end{array}$ & $\begin{array}{r}z_{01} \\
{[\mathrm{~cm}]}\end{array}$ & $\begin{array}{c}x_{1} \\
{[\mathrm{~m}]}\end{array}$ & $\begin{array}{c}z_{02} \\
{[\mathrm{~cm}]}\end{array}$ & Season \\
\hline 1 & 230 & $\begin{array}{r}10.0 \\
3.0 \\
7.0 \\
10.0 \\
\end{array}$ & 75 & $z_{0 w}$ & $\begin{array}{l}\text { winter } \\
\text { spring } \\
\text { summer } \\
\text { fall } \\
\end{array}$ \\
\hline 2 & 240 & $\begin{array}{r}10.0 \\
3.0 \\
7.0 \\
10.0 \\
\end{array}$ & 75 & $z_{0 w}$ & $\begin{array}{l}\text { winter } \\
\text { spring } \\
\text { summer } \\
\text { fall }\end{array}$ \\
\hline 3 & 250 & $\begin{array}{r}10.0 \\
3.0 \\
7.0 \\
10.0\end{array}$ & 75 & $z_{0 w}$ & $\begin{array}{l}\text { winter } \\
\text { spring } \\
\text { summer } \\
\text { fall }\end{array}$ \\
\hline 4 & 260 & $\begin{array}{r}10.0 \\
3.0 \\
7.0 \\
10.0\end{array}$ & 75 & $z_{0 w}$ & $\begin{array}{l}\text { winter } \\
\text { spring } \\
\text { summer } \\
\text { fall }\end{array}$ \\
\hline 5 & 270 & $\begin{array}{r}10.0 \\
3.0 \\
7.0 \\
10.0\end{array}$ & 100 & $z_{0 w}$ & $\begin{array}{l}\text { winter } \\
\text { spring } \\
\text { summer } \\
\text { fall }\end{array}$ \\
\hline 6 & 280 & $\begin{array}{r}10.0 \\
3.0 \\
7.0 \\
10.0 \\
\end{array}$ & 110 & $z_{0 w}$ & $\begin{array}{l}\text { winter } \\
\text { spring } \\
\text { summer } \\
\text { fall }\end{array}$ \\
\hline 7 & 290 & $\begin{array}{r}10.0 \\
3.0 \\
7.0 \\
10.0\end{array}$ & 110 & $z_{0 w}$ & $\begin{array}{l}\text { winter } \\
\text { spring } \\
\text { summer } \\
\text { fall }\end{array}$ \\
\hline 8 & 300 & $\begin{array}{r}10.0 \\
3.0 \\
7.0 \\
10.0\end{array}$ & 150 & $z_{0 w}$ & $\begin{array}{l}\text { winter } \\
\text { spring } \\
\text { summer } \\
\text { fall }\end{array}$ \\
\hline 9 & 310 & $\begin{array}{r}10.0 \\
3.0 \\
7.0 \\
10.0\end{array}$ & 1150 & $z_{0 w}$ & $\begin{array}{l}\text { winter } \\
\text { spring } \\
\text { summer } \\
\text { fall }\end{array}$ \\
\hline
\end{tabular}


Table 6: Roughness lengths and fetches of the flow directions considered for mast 2. $z_{0 w}$ is the upstream water roughness computed from Eq. (1).

\begin{tabular}{|c|c|c|c|c|c|c|c|}
\hline Sector & $\begin{array}{c}\text { Direction } \\
{\left[^{\circ}\right]} \\
\end{array}$ & $\begin{array}{r}z_{01} \\
{[\mathrm{~cm}]} \\
\end{array}$ & $\begin{array}{r}x_{1} \\
{[\mathrm{~m}]} \\
\end{array}$ & $\begin{array}{r}z_{02} \\
{[\mathrm{~cm}]} \\
\end{array}$ & $\begin{array}{r}x_{2} \\
{[\mathrm{~m}]}\end{array}$ & $\begin{array}{c}z_{03} \\
{[\mathrm{~cm}]} \\
\end{array}$ & Season \\
\hline 1 & 230 & $\begin{array}{l}0.5 \\
0.3 \\
5.0 \\
1.9\end{array}$ & 650 & $\begin{array}{r}10.0 \\
3.0 \\
7.0 \\
10.0 \\
\end{array}$ & 975 & $z_{0 w}$ & $\begin{array}{l}\text { winter } \\
\text { spring } \\
\text { summer } \\
\text { fall }\end{array}$ \\
\hline 2 & 240 & $\begin{array}{l}0.5 \\
0.4 \\
5.0 \\
2.2\end{array}$ & 575 & $\begin{array}{r}10.0 \\
3.0 \\
7.0 \\
10.0\end{array}$ & 750 & $z_{0 w}$ & $\begin{array}{l}\text { winter } \\
\text { spring } \\
\text { summer } \\
\text { fall }\end{array}$ \\
\hline 3 & 250 & $\begin{array}{l}0.5 \\
1.0 \\
5.0 \\
2.6\end{array}$ & 600 & $\begin{array}{r}10.0 \\
3.0 \\
7.0 \\
10.0\end{array}$ & 750 & $z_{0 w}$ & $\begin{array}{l}\text { winter } \\
\text { spring } \\
\text { summer } \\
\text { fall }\end{array}$ \\
\hline 4 & 260 & $\begin{array}{l}0.8 \\
1.6 \\
5.0 \\
2.5\end{array}$ & 600 & $\begin{array}{r}10.0 \\
3.0 \\
7.0 \\
10.0\end{array}$ & 775 & $z_{0 w}$ & $\begin{array}{l}\text { winter } \\
\text { spring } \\
\text { summer } \\
\text { fall }\end{array}$ \\
\hline 5 & 270 & $\begin{array}{l}0.9 \\
1.5 \\
5.0 \\
2.3\end{array}$ & 825 & $\begin{array}{r}10.0 \\
3.0 \\
7.0 \\
10.0\end{array}$ & 1200 & $z_{0 w}$ & $\begin{array}{l}\text { winter } \\
\text { spring } \\
\text { summer } \\
\text { fall }\end{array}$ \\
\hline 6 & 280 & $\begin{array}{l}0.9 \\
1.3 \\
5.0 \\
2.3\end{array}$ & 1000 & $\begin{array}{r}10.0 \\
3.0 \\
7.0 \\
10.0\end{array}$ & 1425 & $z_{0 w}$ & $\begin{array}{l}\text { winter } \\
\text { spring } \\
\text { summer } \\
\text { fall }\end{array}$ \\
\hline 7 & 290 & $\begin{array}{l}0.8 \\
1.0 \\
5.0 \\
2.0\end{array}$ & 900 & $\begin{array}{r}10.0 \\
3.0 \\
7.0 \\
10.0\end{array}$ & 1525 & $z_{0 w}$ & $\begin{array}{l}\text { winter } \\
\text { spring } \\
\text { summer } \\
\text { fall }\end{array}$ \\
\hline 8 & 300 & $\begin{array}{l}0.7 \\
0.8 \\
5.0 \\
1.8\end{array}$ & 1125 & 10.0 & 2250 & $z_{0 w}$ & $\begin{array}{l}\text { winter } \\
\text { spring } \\
\text { summer } \\
\text { fall }\end{array}$ \\
\hline 9 & 310 & $\begin{array}{l}0.5 \\
0.6 \\
5.0 \\
1.5\end{array}$ & 1250 & 20.0 & 3100 & $z_{0 w}$ & $\begin{array}{l}\text { winter } \\
\text { spring } \\
\text { summer } \\
\text { fall }\end{array}$ \\
\hline
\end{tabular}


Table 7: Roughness lengths and fetches of the flow directions considered for mast 3. $z_{0 w}$ is the upstream water roughness computed from Eq. (1).

\begin{tabular}{|c|c|c|c|c|c|c|c|}
\hline Sector & $\begin{array}{c}\text { Direction } \\
{\left[{ }^{\circ}\right]}\end{array}$ & $\begin{array}{r}z_{01} \\
{[\mathrm{~cm}]}\end{array}$ & $\begin{array}{l}x_{1} \\
{[\mathrm{~km}]}\end{array}$ & $\begin{array}{r}z_{02} \\
{[\mathrm{~cm}]}\end{array}$ & $\begin{array}{r}x_{2} \\
{[\mathrm{~km}]}\end{array}$ & $\begin{array}{c}z_{03} \\
{[\mathrm{~cm}]}\end{array}$ & Season \\
\hline 1 & 230 & $\begin{array}{l}0.4 \\
0.5 \\
3.8 \\
1.4\end{array}$ & 5.75 & $z_{0 w}$ & & & $\begin{array}{l}\text { winter } \\
\text { spring } \\
\text { summer } \\
\text { fall }\end{array}$ \\
\hline 2 & 240 & $\begin{array}{l}0.5 \\
0.2 \\
4.0 \\
1.2\end{array}$ & 5.3 & $z_{0 w}$ & & & $\begin{array}{l}\text { winter } \\
\text { spring } \\
\text { summer } \\
\text { fall }\end{array}$ \\
\hline 3 & 250 & $\begin{array}{l}0.5 \\
0.5 \\
1.8 \\
1.0 \\
\end{array}$ & 4.7 & $z_{0 w}$ & & & $\begin{array}{l}\text { winter } \\
\text { spring } \\
\text { summer } \\
\text { fall }\end{array}$ \\
\hline 4 & 260 & $\begin{array}{l}0.6 \\
0.9 \\
3.2 \\
2.0\end{array}$ & 2.5 & 0.1 & 4.3 & $z_{0 w}$ & $\begin{array}{l}\text { winter } \\
\text { spring } \\
\text { summer } \\
\text { fall }\end{array}$ \\
\hline 5 & 270 & $\begin{array}{l}0.4 \\
0.7 \\
8.0 \\
2.0\end{array}$ & 2.63 & 0.2 & 4.4 & $z_{0 w}$ & $\begin{array}{l}\text { winter } \\
\text { spring } \\
\text { summer } \\
\text { fall }\end{array}$ \\
\hline 6 & 280 & $\begin{array}{l}0.4 \\
0.5 \\
6.0 \\
1.7\end{array}$ & 2.75 & 0.1 & 4.55 & $z_{0 w}$ & $\begin{array}{l}\text { winter } \\
\text { spring } \\
\text { summer } \\
\text { fall }\end{array}$ \\
\hline 7 & 290 & $\begin{array}{l}0.2 \\
0.3 \\
6.0 \\
1.3\end{array}$ & 0.9 & 0.2 & 5.43 & $z_{0 w}$ & $\begin{array}{l}\text { winter } \\
\text { spring } \\
\text { summer } \\
\text { fall }\end{array}$ \\
\hline 8 & 300 & $\begin{array}{l}0.2 \\
0.3 \\
5.0 \\
1.8\end{array}$ & 1.0 & 0.2 & 7.23 & $z_{0 w}$ & $\begin{array}{l}\text { winter } \\
\text { spring } \\
\text { summer } \\
\text { fall }\end{array}$ \\
\hline 9 & 310 & $\begin{array}{l}0.3 \\
0.5 \\
4.4 \\
0.6\end{array}$ & 0.9 & 0.2 & 10.73 & $z_{0 w}$ & $\begin{array}{l}\text { winter } \\
\text { spring } \\
\text { summer } \\
\text { fall }\end{array}$ \\
\hline
\end{tabular}


Table 8: Roughness lengths and fetches at mast 4. $z_{0 w}$ is the upstream water roughness computed from Eq. (1).

\begin{tabular}{|c|c|c|c|c|c|c|c|c|c|c|c|c|c|}
\hline $\begin{array}{l}\text { Sec- } \\
\text { tor }\end{array}$ & $\begin{array}{l}\text { Dir. } \\
{\left[{ }^{\circ}\right]}\end{array}$ & $\begin{array}{c}z_{01} \\
{[\mathrm{~cm}]}\end{array}$ & $\begin{array}{c}x_{1} \\
{[\mathrm{~km}]}\end{array}$ & $\begin{array}{r}z_{02} \\
{[\mathrm{~cm}]}\end{array}$ & $\begin{array}{r}x_{2} \\
{[\mathrm{~km}]}\end{array}$ & $\begin{array}{r}z_{03} \\
{[\mathrm{~cm}]}\end{array}$ & $\begin{array}{r}x_{3} \\
{[\mathrm{~km}]}\end{array}$ & $\begin{array}{r}z_{04} \\
{[\mathrm{~cm}]}\end{array}$ & $\begin{array}{r}x_{4} \\
{[\mathrm{~km}]}\end{array}$ & $\begin{array}{c}z_{05} \\
{[\mathrm{~cm}]}\end{array}$ & $\begin{array}{r}x_{5} \\
{[\mathrm{~km}]}\end{array}$ & $\begin{array}{c}z_{06} \\
{[\mathrm{~cm}]}\end{array}$ & Season \\
\hline 1 & 230 & $\begin{array}{l}0.7 \\
0.5 \\
0.9 \\
0.8\end{array}$ & 0.6 & 20.0 & 9.3 & 2.0 & 13.5 & 20.0 & 56.25 & $z_{0 w}$ & & & $\begin{array}{l}\text { winter } \\
\text { spring } \\
\text { summer } \\
\text { fall }\end{array}$ \\
\hline 2 & 240 & $\begin{array}{l}0.4 \\
0.5 \\
0.8 \\
1.2\end{array}$ & 0.9 & 30.0 & 9.5 & 2.0 & 14.0 & 30.0 & 48.0 & $z_{0 w}$ & & & $\begin{array}{l}\text { winter } \\
\text { spring } \\
\text { summer } \\
\text { fall }\end{array}$ \\
\hline 3 & 250 & $\begin{array}{l}0.3 \\
0.4 \\
1.0 \\
1.6\end{array}$ & 1.0 & 20.0 & 22.3 & 10.0 & 31.5 & 0.01 & 37.2 & 20.0 & 48.0 & $z_{0 w}$ & $\begin{array}{l}\text { winter } \\
\text { spring } \\
\text { summer } \\
\text { fall }\end{array}$ \\
\hline 4 & 260 & $\begin{array}{l}0.3 \\
0.2 \\
0.6 \\
1.0\end{array}$ & 1.0 & 30.0 & 23.2 & 10.0 & 28.0 & $z_{0 w}$ & & & & & $\begin{array}{l}\text { winter } \\
\text { spring } \\
\text { summer } \\
\text { fall }\end{array}$ \\
\hline 5 & 270 & $\begin{array}{l}0.9 \\
0.3 \\
2.6 \\
1.6\end{array}$ & 0.8 & 30.0 & 26.0 & 10.0 & 30.7 & $z_{0 w}$ & & & & & $\begin{array}{l}\text { winter } \\
\text { spring } \\
\text { summer } \\
\text { fall }\end{array}$ \\
\hline 6 & 280 & $\begin{array}{l}0.9 \\
0.7 \\
1.8 \\
1.7\end{array}$ & 0.6 & 30.0 & 28.0 & 10.0 & 32.0 & $z_{0 w}$ & & & & & $\begin{array}{l}\text { winter } \\
\text { spring } \\
\text { summer } \\
\text { fall }\end{array}$ \\
\hline 7 & 290 & $\begin{array}{l}0.9 \\
0.9 \\
2.1 \\
1.3\end{array}$ & 0.5 & 30.0 & 37.5 & 10.0 & 46.2 & $z_{0 w}$ & & & & & $\begin{array}{l}\text { winter } \\
\text { spring } \\
\text { summer } \\
\text { fall }\end{array}$ \\
\hline 8 & 300 & $\begin{array}{l}1.0 \\
1.2 \\
1.6 \\
1.3\end{array}$ & 0.5 & 30.0 & 40.0 & 5.0 & 48.4 & $z_{0 w}$ & & & & & $\begin{array}{l}\text { winter } \\
\text { spring } \\
\text { summer } \\
\text { fall }\end{array}$ \\
\hline 9 & 310 & $\begin{array}{l}1.1 \\
1.0 \\
1.6 \\
1.5\end{array}$ & 0.5 & 30.0 & 56.25 & $z_{0 w}$ & & & & & & & $\begin{array}{l}\text { winter } \\
\text { spring } \\
\text { summer } \\
\text { fall }\end{array}$ \\
\hline
\end{tabular}




\subsection{References}

Bradley, E.F. (1968). A micrometeorological study of velocity profiles and surface drag in the region modified by a change in surface roughness. Quart. J.R. Met. Soc., 94, 361-379.

Brutseart, W. (1975). Comments on surface roughness parameters and the height of dense vegetation. J. Met. Soc. Japan, 53, 96-97.

Businger, J.A. (1972). The atmospheric boundary layer. In: Remote Sensing of the Troposphere. Ed. V.E. Derr (US Govt. Printing Office, Wash. DC $\mathrm{COM} / 72 / 51061) 6 / 1-6 / 51$.

ESDU 72026 (1972). Characteristics of wind speed in the lowest layers of the atmosphere near the ground: strong winds. Eng. Sci. Data Unit Ltd., 251 Regent St., London W1R 7AD.

Geernaert, G.L., S.E. Larsen and F. Hansen (1987). Measurements of the wind stress, heat flux, and turbulence intensity during storm conditions over the North Sea. J. Geophys. Res., 92, 13127-13139.

Hedegaard, K. and S.E. Larsen (1982). Wind speed and directional changes due to terrain effects revealed by climatological data from two sites in Jutland. Ris $\varnothing-\mathrm{R}-434$.

Jensen, N.O., E.L. Petersen and I. Troen (1984). Extrapolation of mean wind statistics with special regard to wind energy application. WCP86. WMO.

Jensen, N.O. and Peterson, E.W. (1977). Wind flow near the surface over nonuniform terrain. Report of progress for the year 1976 (progress report for US Army Grant, available at Ris $\varnothing$ National Laboratory).

Jensen, N.O. (1978): Change of surface roughness and the planetary boundary layer. Quart. J.R. Met. Soc.. 104, 351-356.

Larsen, S.E., K. Hedegaard and I. Troen (1982): The change of terrain roughness problems extended to mesoscale fetches. In: Proc. First International Conference on Meteorology and Air/Sea Interaction (Amer. Meteor. Soc., Boston, USA and KNMI, the Netherlands), 8-13.

Larsen, S.E. and N.O. Jensen (1983): Summary and interpretation of some Danish climate statistics. Ris $\varnothing-\mathrm{R}-399$.

Mahrt, L. and S.E. Larsen (1982): Small scale drainage front. Tellus, 34, 579-587. 
Panofsky, H.A. (1973): Tower climatology. In: Workshop on Micrometeorology. Ed. D.A. Haugen (Amer. Meteorol. Soc., Boston, USA), 177-216.

Petersen, E.L. and I. Troen (1986): The European Wind Atlas. In: Proc. of the EWEC'86 Conference, Rome, Italy, 7-9 October, 1986. 55-65.

Peterson, E.W. (1972): Relative importance of terms in the turbulent energy and momentum equations as applied to the problem of a surface roughness change. J. Atmos. Sci., 29, 1470-1476.

Peterson, E.W., N.O. Jensen and J. Højstrup (1979). Observations of downwind development of wind speed and variance profiles at Bognæs and comparison with theory. Quart. J. Roy. Met. Soc., 105, 521-529.

Rao, K.S., J.C. Wyngaard and D.R. Coté 1974): The structure of the twodimensional internal boundary layer over a sudden change of surface roughness. J. Atmos. Sci., 26, 432-440.

Taylor, P.A. (1969). The planetary boundary layer above a change in surface roughness. J. Atmos. Sci., 26, 432-440.

Tennekes, H. (1973): Similarity laws and scale relations in planetary boundary layers. In: Workshop on Micrometeorology. Ed. D.A. Haugen, Amer. Meteor. Soc., Boston, USA, 177-216.

Thom, A.S. (1971): Momentum absorption by vegetation. Quart. J. R. Met. Soc., 97, 414-428. 